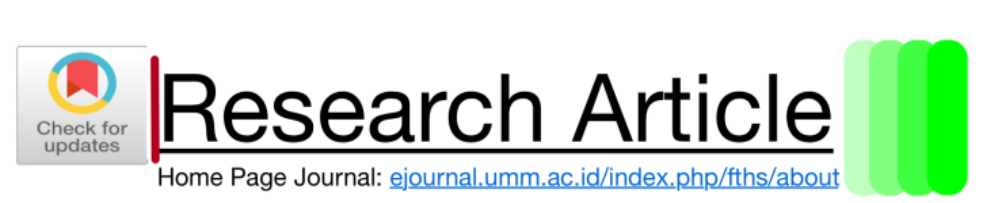

DOI. $10.22219 /$ fths.v5i1.18776

Received: 21 November 2021

Accepted: 25 January 2022

Available online: 31 January 2022

\title{
The Effect of The Ratio of Beetroot Juice with Pineapple Core Juice and Carrageenan Concentration from Seaweed (Eucheuma cottonii) on Jelly Candy Quality
}

\author{
Faradiba Hijriani Harahap $^{1 *}$, Noor Harini ${ }^{1}$, Warkoyo ${ }^{1}$, Rista Anggriani ${ }^{1}$ \\ 1Department of Food Technology, Faculty of Agriculture and Animal Science, University of \\ Muhammadiyah Malang, Malang, Indonesia \\ *Corresponding author email: faradiba.hijriani@gmail.com
}

\begin{abstract}
Carrageenan is a gelling agent that can be extracted using coconut water solvent. The ability of carrageenan to form a gel can be applied in various products, such as jelly candy. Beetroot is one of the raw materials that can be used in making jelly candy. Beetroot is known to contain various vitamins and minerals as well as betalain pigments which are very beneficial for the body. The weakness of beetroot is its distinctive aroma and taste that is considered unpleasant. Therefore, the pineapple core was added to reduce it. This research aims to determine the interaction between the ratios of beetroot juice and pineapple core juice with carrageenan concentrations on the quality of jelly candy. This research consisted of two main stages consisted of carrageenan extraction, and followed by application into jelly candy made from the beetroot-pineapple core. This study used a factorial Randomized Block Design (RBD) with first factor (S) the ratio of beetroot juice and pineapple core juice (100\%: 0\%, 75\%: 25\%, 50\%: $50 \%$ ) and second factor (K) concentration of carrageenan $(3 \%, 3.5 \%, 4 \%)$ with 3 replications. The results showed that there were interactions between treatments on moisture content, ash content, texture, organoleptic of color, aroma, taste, and texture of jelly candy. The ratio of $50 \%$ beetroot juice : $50 \%$ pineapple core and 4\% carrageenan concentration was known as the best treatment with a moisture content of $14.79 \%$, ash content $0.72 \%$, reducing sugar $1.81 \%$, antioxidant activity $71.23 \%$, texture $59,6 \mathrm{~N}$, brightness $(L) 34.53$, redness (at) 0.3 , yellowness (b+) 0.83, color 4.2 (attractive), aroma 4 (pleasant), taste 4.16 (good), texture 3.96 (slightly chewy).
\end{abstract}

Keywords: beetroot, carrageenan, jelly candy, pineapple core

\section{INTRODUCTION}

Eucheuma cottonii is a type of seaweed that can produce carrageenan from the kappa carrageenan fraction. The quality of carrageenan is affected by many factors, including the type of solvent. Commonly, carrageenan is extracted using chemical solvents such as $\mathrm{KOH}$ and $\mathrm{NaOH}$. Natural solvents can replace the role of chemical solvents, one of which is coconut water. A previous study done by Cahyanti (2019) showed the best treatment was using medium maturity coconut 
water and a 1:20 ratio of seaweed and coconut water. The extracted carrageenan had met FAO standards with a yield of $44.888 \%$, viscosity $13500 \mathrm{cps}$, gel strength $573.2255 \mathrm{~g} / \mathrm{cm} 2$, moisture content $6.412 \%$, and ash content $16.877 \%$.

Carrageenan's function as a gelling agent plays an important role in the texture of the food product. Carrageenan has stable properties in acidic solutions and forms a strong gel in a solution containing calcium salts, the resulting gel is not hard, soft, elastic, tends to be stable without syneresis (Diharmi et al., 2011). The gel-forming ability of carrageenan can be applied in various food products, one of which is jelly candy.

According to SNI 3547-2:2008, jelly candy is a soft textured candy, which is processed with the addition of hydrocolloid components such as carrageenan which is used to modify the texture to produce a chewy product. Over time, public awareness of functional foods is also increasing. The food consumed is not only in terms of quantity but also a quality that provides a positive health effect. In the last ten years, market and academic research reports an increasing awareness and consumer interest in health issues and functional food. The increase in sales of functional foods in 2003-2008 was around $40 \%$ and is estimated to continue to increase up until now (Stojanavic et al., 2013). There have been many innovations in making jelly candy with the addition of vegetables and fruits. One of the raw materials that can be used in making jelly candy is beetroot.

Beetroot has a purplish red color that comes from betalain pigments. Betalain pigments can be used as an alternative to anthocyanin dyes contained in other types of red fruit because of better stability and resistance, especially at low acidic $\mathrm{pH}$. Beetroot is also known to have various vitamins and minerals. The content of vitamins and betalain compounds in beetroot is known to have potential functional properties as antimicrobials and antioxidants (Slavov et al., 2013). The weakness of beetroot is the unpleasant taste and aroma that is also known as an earthy taste. Previous research done by Hanifan et al. (2016) showed that the more addition of beetroot juice, the less favorable the jelly candy is because the aroma tends to smell unpleasant. Therefore, it is necessary to add another ingredient that has a fresh aroma and taste to reduce the unpleasant aroma of beetroot, such as pineapple core.

Pineapple core is rarely consumed and becomes waste. Zulkifli et al. (2018) stated pineapple core has great potential because it still has a distinctive pineapple aroma, which comes from volatile components, namely methyl ester, and ethyl ester groups. Previous research by Zulkifli et al. (2018) in the making of carrotpineapple core jelly candy, it is known that the unpleasant aroma of carrots can be reduced by the aroma of pineapple core thereby increasing the value of panelist preference. 
This research aimed to determine the effect of ratios of beetroot juice with pineapple core juice and concentrations of carrageenan from seaweed (Eucheuma cottonii) to obtain jelly candy with good quality and acceptable.

\section{RESEARCH METHODS}

\section{Materials}

The raw materials used include beetroot free of physical defects with harvest age of 3 months, size 150-180 g, diameter $\pm 8 \mathrm{~cm}$ obtained from beetroot farm in Batu, Blitar pineapple type Queen free of physical defects maturity level $100 \%$ with solid texture, diameter $\pm 12 \mathrm{~cm}$ purchased at the Landungsari market, Eucheuma cottonii seaweed from the Karimun Java sea (Central Java), medium maturity coconut water (6 - 11 months) purchased from the Landungsari market, table sugar, glucose syrup, water, citric acid. The materials used for analysis process include distilled water, isopropyl alcohol 99\% (technical), Luff Schrool, KI $20 \%, \mathrm{H}_{2} \mathrm{SO}_{4} 26.5 \%$, starch indicator $0.01 \mathrm{~N}, \mathrm{Na}_{2} \mathrm{~S}_{2} \mathrm{O}_{3} 0.1 \mathrm{~N}, \mathrm{DPPH}$ (2,2-diphenyl-1picrylhydrazyl), ethanol $96 \%$ (technical).

\section{Equipments}

The equipments used included digital scales (SF-400), cabinet dryer (Wanodi 08), water bath shakers (Memmert WNB 14), texture analyzer (Shimadzu EZ Test EZ-SX 500N), viscometer, oven (WTC binder 7200 type E53 No 89749), analytical scales (Pioneer Ohaus PA413), vortex (type M37610-33), UV-VIS spectrophotometer (Shimadzu UV-1800), centrifuge (PLC Series Type Lab 08), color reader (Konica Minolta CR-10), desiccator (Glaswerk Waertheim 6132), hot plate (Maspion S 300), furnace (Ney Type M-525 Series II), titration set, condensor, refrigerator, crucible, beaker glass, buchner funnel, mortar and pestle, measuring flask, erlenmeyer, measuring cup, measuring pipette, filler pipette, cuvette, tube centrifuge, test tube rack, filter cloth, 80 mesh sieve, thermometers, pan, jelly mold.

\section{Research Design}

This research was conducted in two stages. The first stage was carrageenan extraction from Eucheuma cottonii. The second stage was the application of extracted carrageenan into jelly candy made from the beetroot and pineapple core. The second stage in the research used a factorial Randomized Block Design (RBD) of 2 factors. The first factor was the ratio of beetroot juice and pineapple core juice $(100 \%: 0 \%, 75 \%: 25 \%, 50 \%: 50 \%)$, and the second factor was carrageenan concentrations $(3 \%, 3.5 \%, 4 \%)$. The treatments were repeated 3 times.

\section{Extraction of Carrageenan}


Extraction of carrageenan was done by referring to previous research by Cahyanti (2019). Dried Eucheuma cottonii was cut to a size of $\pm 1 \mathrm{~cm}$ and then weighed approximately 15 grams. After that, was washed and soaked in distilled water with a ratio of 1:40 for 15 minutes. Wet seaweed was put into erlenmeyer containing coconut water as much as 1:20 of the weight of dry seaweed, then were extracted using a water bath shaker at a temperature of $90^{\circ} \mathrm{C}$ for 2 hours. Thereafter, the filtrate was filtered and collected into beaker glass containing isopropanol alcohol with a ratio of 1:2 to the coconut water and settled for 30 minutes. After that, carrageenan formed were washed using distilled water. Wet carrageenan then dried in a cabinet dryer at $60^{\circ} \mathrm{C}$ for 24 hours. Dried carrageenan then was ground and sieved to obtain fine size carrageenan.

\section{Preparation of Jelly Candy}

\section{Beetroot Juice Production}

The making of beetroot juice was done by following the method of Datuyanan et al. (2020). Beetroot sorted then washed with clean running water. Beetroot then peeled and cut into a cube. Beetroot then was blanched at $60^{\circ} \mathrm{C}$ for 3 minutes. After that, the beetroot blended with the addition of water 1:1. Then was strained to get the beetroot juice.

\section{Pineapple Core Juice Production}

The making of pineapple core juice was done by following the method of Giyarto et al. (2019). The pineapple core was washed in running water then was cut into small sizes. The pineapple core then was blended with water with a 1:1 ratio. The blended pineapple core was then strained to separate from the pulp.

\section{Jelly Candy Production}

The production of jelly candy was done by referring to the modified method of Malik (2010). Beetroot and pineapple core juice were each measured according to each treatment $(\mathrm{S} 1=100 \%: 0 \%, \mathrm{~S} 2=75 \%: 25 \%, \mathrm{~S} 3=50 \%: 50 \%)(\mathrm{v} / \mathrm{v})$ to reach a total juice of $200 \mathrm{~mL}$. The mixture was heated to a temperature of $40^{\circ} \mathrm{C}$. Then, $25 \%$ sucrose (w/v) and 25\% glucose (w/v) were added and stirred during heating. The extracted carrageenan from seaweed (Eucheuma cottonii) was added based on each treatment $(\mathrm{K} 1=3 \%, \mathrm{~K} 2=3.5 \%, \mathrm{~K} 3=4 \%)(\mathrm{w} / \mathrm{v})$. The mixture was heated until homogeneous to a temperature of $80-90^{\circ} \mathrm{C}$, then maintained for 10 minutes. After that, the heat was off and $0.3 \%(\mathrm{w} / \mathrm{v})$ citric acid was added. The mixture was poured into a jelly mold pan. Then, was cooled at room temperature of $28^{\circ} \mathrm{C}$ for 2 hours. The jelly candy was placed into the refrigerator at $5^{\circ} \mathrm{C}$ for 10 hours. After that, jelly candy was removed from the mold and cut evenly, then dried at $60^{\circ} \mathrm{C}$ for 24 hours.

\section{Parameters Analysis}


Analysis of extracted carrageenan includes yield (AOAC, 2005), moisture content (AOAC, 2005), viscosity (Utomo, 2016), gel strength (Distantina et al., 2010), while analysis of jelly candy includes moisture content (AOAC, 2005), ash content (Sudarmadji et al., 2007), reducing sugar (Sudarmadji et al., 2007), antioxidant activity (Yue and $\mathrm{Xu}, 2008$ ), texture (Shaliha et al., 2017), color (Souripet, 2015), and organleptic tests (color, aroma, taste, texture).

\section{Statistical Analysis}

Statistical analysis was performed by Analysis of Variance (ANOVA). If the treatment was significantly affected the observed parameters, then the DMRT $a=$ $5 \%$ further test is carried out. Analysis was done using SPSS 17 software.

\section{RESULT AND DISCUSSION}

\section{Raw Materials Characteristics}

\section{Extracted Carrageenan with Coconut Water Solvent}

Based on Table 1, carrageenan analysis was carried out to determine the physical and chemical properties of the extracted carrageenan and to compare the research results with the carrageenan quality standard.

Table 1. Characteristics of Extracted Carrageenan

\begin{tabular}{lcc}
\hline \multicolumn{1}{c}{ Parameters } & Result & Standart \\
\hline Yield (\%) & 56.74 & Min. $25^{\mathrm{a}}$ \\
Moisture Content (\%) & 12.77 & Max. $12^{\mathrm{b}}$ \\
Viscosity (cPs) & 171.67 & Min $5^{\mathrm{b}}$ \\
Gel strength $\left(\mathrm{g} / \mathrm{cm}^{2}\right)$ & 69.00 & $20-500^{\mathrm{b}}$ \\
\hline
\end{tabular}

$\mathrm{a}=$ BSN (2017), b= FAO (2014)

The results showed that the yield value produced has met the requirements of BSN (2017) which is a minimum of $25 \%$. The low $\mathrm{pH}$ of coconut water could break down the cell wall of seaweed so the extraction process went optimally (Distantina et al., 2010). Potassium in coconut water is needed in the carrageenan extraction process, where carrageenan is sensitive to potassium ions which can increase the ionic strength in the polymer chain, so that the intermolecular forces are completely dissolved. Coconut water with a medium maturity level has the highest potassium content that is $158.51 \mathrm{mg} / \mathrm{L}$, high potassium content causes a lot of carrageenans to be extracted thus resulting in a high yield value (Cahyanti, 2019).

The result showed that the moisture content is slightly exceeds the FAO standard, which is a maximum of $12 \%$. This can be caused by an uneven drying process. The factors that influence the drying process include temperature, humidity, airflow rate, initial moisture content of the material, and the final moisture content of the material (Rahayuningtyas and Kuala, 2016). 
The viscosity value has met the FAO standard, which is at least $5 \mathrm{cPs}$. K+ ions in coconut water could transeliminate the groups that are attached to the galactose group to form a $\mathrm{K}_{2} \mathrm{SO}_{4}$ salt. This salt can reduce the charge along the polymer chain and reduce the repulsion between the sulfate groups which results in weakening hydrophilic properties and decreasing viscosity value (Bunga et al., 2013). The low sulfate content results in the formation of a strong 3,6-anhydro-Dgalactose framework but low viscosity. The viscosity of carrageenan is linear to the amount of sulfate and not linear to the gel strength of carrageenan (Campo et al., 2009).

The gel strength has met the FAO standard, which is in a range of 20-500 $\mathrm{g} / \mathrm{cm}^{2}$. The ability of carrageenan to form gel is indicated by the formation of anhydrogalactose. According to Distantina et al (2010) the sulfate content in carrageenan affects the value of gel strength. The higher the sulfate content, the lower the gel strength. Potassium in coconut water is able to reduce the repulsion between sulfate ester groups, causing an increase in the value of gel strength.

\section{Beetroot and Pineapple Core}

Based on Table 2, it was known that characteristics of beetroot and pineapple were compared to the literatures.

Table 2. Characteristics of Beetroot and Pineapple Core

\begin{tabular}{lrrrr}
\hline Parameters & Beetroot & Literature & $\begin{array}{r}\text { Pineapple } \\
\text { Core }\end{array}$ & Literature \\
\hline Antioxidant Activity (\%) & 63.14 & $51.06^{\mathrm{a}}$ & 85.85 & - \\
Reducing Sugar (\%) & 3.82 & $4.20^{\mathrm{b}}$ & 6.44 & $8.2^{\mathrm{c}}$ \\
\hline
\end{tabular}

$\mathrm{a}=$ Timur (2019), b = Kale et al. (2018), c= Hossain et al. (2015)

The different result from the literature may occur due to different sources of fruit, different planting environment, planting time, tuber size, harvest age and, storage conditions. The antioxidant compounds contained in beetroot include flavonoid compounds (350-2760 mg/kg), betacyanin $(840-900 \mathrm{mg} / \mathrm{kg})$, betanin (300$600 \mathrm{mg} / \mathrm{kg})$, ascorbic acid $(50-868 \mathrm{mg} / \mathrm{kg})$ and, carotenoids $(0.44 \mathrm{mg} / \mathrm{kg})$ (Novatama et al., 2016). Meanwhile, pineapple core contains vitamin $\mathrm{C}$ and carotenoids. Ascorbic acid or vitamin $\mathrm{C}$ is an effective antioxidant that can inhibit free radicals that attack normal cells in the body.

The reducing sugar of both materials showed slight differences from the literature. The reducing sugars are a group of sugars that can reduce electronaccepting compounds. All monosaccharides and disaccharides (except sucrose) act as reducing sugars. The reducing property of sugar is determined by the presence or absence of a free reactive hydroxyl group (OH) (Giyarto, 2019). The overall sugar content in beetroot comes from simple sugars, namely glucose and, sucrose. Sugar 
in the pineapple core consists of three main components, namely sucrose, glucose, and fructose (Hossain et al., 2015).

\section{Quality of Jelly Candy}

\section{Moisture Content}

Based on the analysis of variance, it is known that there is an interaction $(\mathrm{P}<0,05)$ between the two factors on the moisture content of jelly candy.

Table 3. Moisture Content of Jelly Candy

\begin{tabular}{lc} 
Treatments & Moisture Content (\%) \\
\hline S1K1 (100\% Beetroot: 0\% Pineapple Core + 3\% Carrageenan) & $17.89^{\mathrm{g}}$ \\
S1K2 (100\% Beetroot: 0\% Pineapple Core + 3,5\% Carrageenan) & $16.57^{\mathrm{def}}$ \\
S1K3 (100\% Beetroot: 0\% Pineapple Core + 4\% Carrageenan) & $14.20^{\mathrm{a}}$ \\
S2K1 (75\% Beetroot : 25\% Pineapple Core + 3\% Carrageenan) & $17.18^{\mathrm{fg}}$ \\
S2K2 (75\% Beetroot : 25\% Pineapple Core + 3,5\% Carrageenan) & $16.23^{\mathrm{de}}$ \\
S2K3 (75\% Beetroot : $25 \%$ Pineapple Core + 4\% Carrageenan) & $15.14^{\mathrm{bc}}$ \\
S3K1 (50\% Beetroot : 50\% Pineapple Core + 3\% Carrageenan) & $16.84^{\mathrm{ef}}$ \\
S3K2 (50\% Beetroot : 50\% Pineapple Core + 3,5\% Carrageenan) & $15.85^{\mathrm{cd}}$ \\
S3K3 (50\% Beetroot : 50\% Pineapple Core + 4\% Carrageenan) & $14.79^{\mathrm{ab}}$ \\
\hline
\end{tabular}

Mean followed by different letters in the same column differs significantly $(\mathrm{P} \leq 0.05)$

The moisture content in each treatment has met the standards set by SNI 3567.02.2008 with a maximum moisture content of $20 \%$. The moisture content of the jelly candy decreased along with the increase of pineapple core juice. The natural pectin content in raw materials can affect the moisture content of the product. Beetroot is known to have a pectin content of $30 \%$ (Nuraini and Karyantina, 2019). Pineapple core is also known to still have pectin content but only $1.82 \%$ (Zulkifli et al., 2018). Pectin is known as a polymer compound that can trap water. Therefore, the higher the pectin content, the higher the moisture content as well.

The higher concentration of carrageenan resulting in lower moisture content. The carrageenan could decrease the free water that evaporates during the drying process. Carrageenan can combine or crosslink polymer chains to form a continuous three-dimensional structure. This structure forms a strong and rigid structure thus the amount of free water and adsorbed water in the product decreases (Sidi et al., 2014). The sulfate group of carrageenan is negatively charged along the polymer chains and is hydrophilic which can bind water and other hydroxyls. Carrageenan is capable of binding water in the presence of a large number of $\mathrm{OH}$-groups (Agustin and Putri, 2014). The result is similar to previous research by Fajarini et al. (2018) where the higher the carrageenan concentration, the lower the moisture content of the grape peels jelly candy.

\section{Ash Content}


Based on the analysis of variance, it is known that there is an interaction $(\mathrm{P}<0,05)$ between the two factors on the ash content of jelly candy.

Table 4. Ash Content of Jelly Candy

\begin{tabular}{ll}
\hline \multicolumn{1}{c}{ Treatments } & Ash Content (\%) \\
\hline S1K1 (100\% Beetroot: 0\% Pineapple Core + 3\% Carrageenan) & $0.39^{\mathrm{a}}$ \\
S1K2 (100\% Beetroot: 0\% Pineapple Core $+3,5 \%$ Carrageenan) & $0.47^{\mathrm{bc}}$ \\
S1K3 (100\% Beetroot: 0\% Pineapple Core $+4 \%$ Carrageenan) & $0.54^{\mathrm{d}}$ \\
S2K1 (75\% Beetroot : 25\% Pineapple Core $+3 \%$ Carrageenan) & $0.42^{\mathrm{ab}}$ \\
S2K2 (75\% Beetroot : 25\% Pineapple Core + 3,5\% Carrageenan) & $0.52^{\mathrm{cd}}$ \\
S2K3 (75\% Beetroot : 25\% Pineapple Core + 4\% Carrageenan) & $0.68^{\mathrm{e}}$ \\
S3K1 (50\% Beetroot : 50\% Pineapple Core + 3\% Carrageenan) & $0.51^{\mathrm{cd}}$ \\
S3K2 (50\% Beetroot : 50\% Pineapple Core + 3,5\% Carrageenan) & $0.68^{\mathrm{e}}$ \\
S3K3 (50\% Beetroot : 50\% Pineapple Core + 4\% Carrageenan) & $0.72^{\mathrm{e}}$ \\
\hline
\end{tabular}

Mean followed by different letters in the same column differs significantly $(\mathrm{P} \leq 0.05)$

The ash content in each treatment has met the standard set by SNI 3567.02.2008 with a maximum ash content of $3 \%$. The ash content of jelly candy tends to increase along with the increase of pineapple core juice. Raw materials with high mineral content will increase the ash content of jelly candy (Zulkifli et al., 2018). Pineapple core has an ash content of $2.10 \%$ includes calcium, phosphorus, and iron (Paramita et al., 2021). Meanwhile, beetroot has an ash content of $1.07 \%$ includes sodium, potassium, manganese, iron, zinc and, copper (Zainuddin et al., 2014).

The higher concentration of carrageenan resulting to a higher ash content. Minerals in the product can be bound by the carrageenan three-dimensional structure. Carrageenan itself has a fairly high mineral content (Fajarini et al., 2018). Processing techniques and the sanitation during the carrageenan extraction process affect the ash content as well, where the lack of washing process can increase the ash content due to excess potassium ion residue in carrageenan.

\section{Reducing Sugar}

Based on the analysis of variance, it is known that there is no interaction $(\mathrm{P}>0,05)$ between the two factors on the reducing sugar of jelly candy. However, both the ratio of beetroot juice and pineapple core juice, also the carrageenan concentration significantly affected reducing sugar. The higher amount of pineapple core juice increases the reducing sugar. Initial analysis showed that reducing sugar of pineapple core is higher than beetroot. Furthermore, the hydrolysis of sucrose can increase the reducing sugar. The high levels of reducing sugar can be caused by the heating process that triggers the inversion of sucrose into glucose and fructose (Meilianti, 2020).

Table 5. Reducing Sugar of Jelly Candy by Ratio of Beetroot Juice with Pineapple Core Juice and Carrageenan Concentration

\begin{tabular}{cc}
\hline Treatments & Reducing Sugar (\%) \\
\hline Ratio of Beetroot Juice : Pineapple Core Juice &
\end{tabular}




\begin{tabular}{lc}
\hline S1 (100\% Beetroot : 0\% Pineapple Core) & $1.321^{\mathrm{a}}$ \\
S2 (75\% Beetroot : 25\% Pineapple Core) & $1.451^{\mathrm{a}}$ \\
S3 (50\% Beetroot : 50\% Pineapple Core) & $1.646^{\mathrm{b}}$ \\
\hline Carrageenan Concentration (\%) & $1.341^{\mathrm{a}}$ \\
K1 (3\% Carrageenan) & $1.472^{\mathrm{ab}}$ \\
K2 (3.5\% Carrageenan) & $1.605^{\mathrm{b}}$ \\
K3 (4\% Carrageenan) &
\end{tabular}

Mean followed by different letters in the same column differs significantly $(\mathrm{P} \leq 0.05)$

The higher concentration of carrageenan increases the reducing sugar. This is because carrageenan has a galactan molecule with galactose as the main unit, which has a reactive and reductive hydroxyl $(\mathrm{OH})$ group at the end of its structure. This result is similar to previous research (Giyarto, 2019) which states that a higher amount of carrageenan will increase the amount of reducing sugar of pineapple core jelly candy. Overall, the reducing sugar value of all treatments has met the SNI 3547.02:2008 with a maximum reducing sugar of $25 \%$.

\section{Antioxidant Activity}

Based on the analysis of variance, it is known that there is no interaction $(\mathrm{P}>0,05)$ between the two factors on the antioxidant activity of jelly candy. However, the ratio of beetroot juice and pineapple core juice significantly affected antioxidant activity. Meanwhile, the carrageenan concentration has no significant effect on antioxidant activity.

Table 6. Antioxidant Activity of Jelly Candy by Ratio of Beetroot Juice and Pineapple Core Juice

\begin{tabular}{lc}
\hline \multicolumn{1}{c}{ Treatments } & $\begin{array}{c}\text { Antioxidant Activity } \\
(\%)\end{array}$ \\
\hline Ratio of Beetroot Juice : Pineapple Core Juice & \\
S1 (100\% Beetroot : 0\% Pineapple Core) & $62.97^{\mathrm{a}}$ \\
S2 (75\% Beetroot : 25\% Pineapple Core) & $68.62^{\mathrm{b}}$ \\
S3 (50\% Beetroot : $50 \%$ Pineapple Core) & $71.77^{\mathrm{b}}$ \\
\hline
\end{tabular}

Mean followed by different letters in the same column differs significantly $(\mathrm{P} \leq 0.05)$

Antioxidant activity tends to increase as the amount of pineapple core juice increases. Based on the initial raw materials analysis, antioxidant activity of pineapple core is higher than beetroot. Pineapple contains vitamin $\mathrm{C}$ and vitamin A which known as great antioxidant agents. Phenolic compounds in the ethyl acetate fraction present in the core, peel and flesh of pineapple are flavonoid compounds that easily release protons (hydrogen) so that they are good at reducing free radicals (Hayat et al., 2015). Pineapple is also known to contain carotenoid pigments and xanthophylls. Beetroot contains vitamin A, vitamin $\mathrm{C}$ also betalain pigments consisting of betacyanins and betaxanthins which have functional properties as antimicrobial and antioxidants (Slavov et al., 2013). 


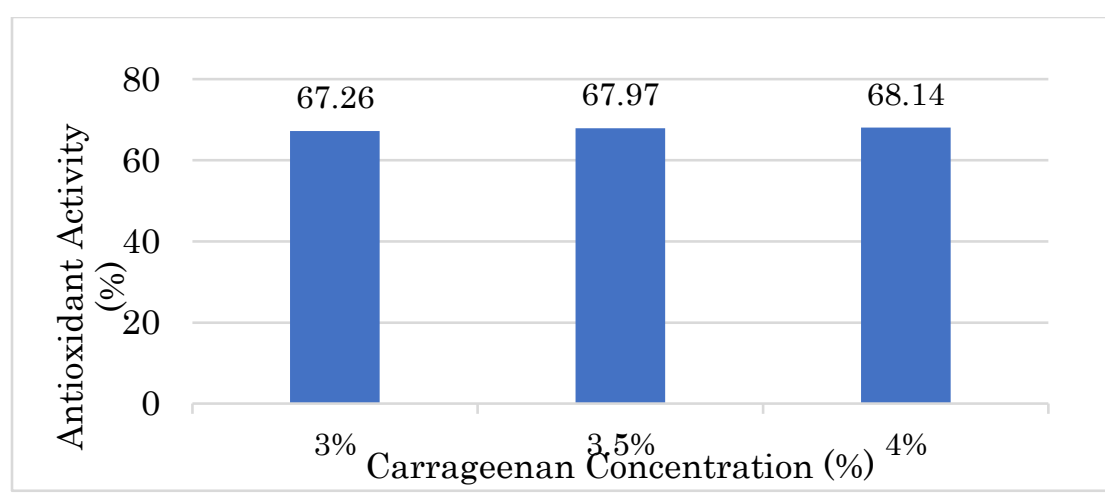

Figure 1. Antioxidant Activity of Jelly Candy by Carrageenan Concentration

Carrageenan concentration had no significant effect on the antioxidant activity of jelly candy. Carrageenan is extracted from Eucheuma cottonii which actually also contains antioxidants including flavonoid compounds, triterpenoids, steroids and alkaloids (Andriani et al., 2015). The antioxidant activity is not significantly different because of the carrageenan added in a small concentration in the range of $3 \%-4 \%$.

\section{Texture}

Based on the analysis of variance, it is known that there is an interaction $(\mathrm{P}<0,05)$ between the two factors on the texture of jelly candy.

Table 7. Texture of Jelly Candy

\begin{tabular}{ll}
\hline \multicolumn{1}{c}{ Treatments } & Texture $(\mathrm{N})$ \\
\hline S1K1 (100\% Beetroot: 0\% Pineapple Core + 3\% Carrageenan) & $21.1^{\mathrm{a}}$ \\
S1K2 (100\% Beetroot: 0\% Pineapple Core + 3,5\% Carrageenan) & $48.6^{\mathrm{cd}}$ \\
S1K3 (100\% Beetroot: 0\% Pineapple Core + 4\% Carrageenan) & $52.5^{\mathrm{cd}}$ \\
S2K1 (75\% Beetroot : 25\% Pineapple Core + 3\% Carrageenan) & $31.8^{\mathrm{ab}}$ \\
S2K2 (75\% Beetroot : 25\% Pineapple Core + 3,5\% Carrageenan) & $40.2^{\mathrm{bc}}$ \\
S2K3 (75\% Beetroot : 25\% Pineapple Core + 4\% Carrageenan) & $58.4^{\mathrm{d}}$ \\
S3K1 (50\% Beetroot : 50\% Pineapple Core + 3\% Carrageenan) & $53.5^{\mathrm{cd}}$ \\
S3K2 (50\% Beetroot : 50\% Pineapple Core + 3,5\% Carrageenan) & $55.5^{\mathrm{d}}$ \\
S3K3 (50\% Beetroot : 50\% Pineapple Core + 4\% Carrageenan) & $59.6^{\mathrm{d}}$ \\
\hline
\end{tabular}

Mean followed by different letters in the same column differs significantly $(\mathrm{P} \leq 0.05)$

The result showed the texture of the jelly candy tends to increase as the pineapple core juice increases. The natural sugar content affects the texture of jelly candy. Analysis of raw materials shows that pineapple core has a higher reducing sugar content. Reducing sugar will increase the viscosity by binding water to the product. Sugar can bind water causes the moisture content in food to decrease (Engka et al., 2016). This result is in accordance with previous research on the making of lempok star fruit, where the more sugar content in the fruit the harder the gel texture (Imaduddin et al., 2017).

The higher the carrageenan concentration, increase the texture of jelly candy. Carrageenan can form a gel, where the polymer chains will form a 
continuous three-dimensional structure that will bind water to create a strong and rigid structure. This ability to bind water also causes the space between particles to become narrow so that the solution becomes stiff and strong (Saputri et al., 2021). The increase in texture value is also related to the moisture content of the product. The lower the moisture content indicates the free water content in the product is decreasing so that the resulting texture is harder and requires a higher force to deform (Samantha et al., 2019).

\section{Color Intensity}

Based on the analysis of variance, it is known that there is no interaction $(\mathrm{P}>0,05)$ between the two factors on the color intensity of jelly candy. However, the ratio of beetroot juice and pineapple core juice significantly affected color intensity, as shown on the table 8. Meanwhile, the carrageenan concentration has no significant effect on color intensity, as shown on the figure 2 .

Table 8. Color Intensity of Jelly Candy by Ratio of Beetroot Juice and Pineapple Core Juice

\begin{tabular}{lccc}
\hline \multicolumn{1}{c}{ Treatments } & Brightness (L) & Redness (a+) & Yellowness (b+) \\
\hline Ratio of Beetroot Juice : Pineapple Core Juice & & & \\
S1 (100\% Beetroot : 0\% Pineapple Core) & $25.67^{\mathrm{a}}$ & $0.54^{\mathrm{b}}$ & $0.42^{\mathrm{a}}$ \\
S2 (75\% Beetroot : 25\% Pineapple Core) & $27.95^{\mathrm{b}}$ & $0.41^{\mathrm{a}}$ & $0.51^{\mathrm{a}}$ \\
S3 (50\% Beetroot : $50 \%$ Pineapple Core) & $34.21^{\mathrm{c}}$ & $0.33^{\mathrm{a}}$ & $0.80^{\mathrm{b}}$ \\
\hline
\end{tabular}

Mean followed by different letters in the same column differs significantly $(\mathrm{P} \leq 0.05)$

The color intensity of the jelly candy is affected by the pigment contained in the fruit. Beetroot has a betalain pigment which is a combination of betacyanin pigment and betaxanthin pigment, these pigments resulting in a deep and dark red color (Lembong and Utama, 2021). Pineapple fruit naturally contains carotenoid pigments, namely carotene and xanthophyll, where also contribute to a yellowish color (Zulkifli et al., 2018).

The higher ratio of beetroot produces darker color, so the brightness level tends to decrease. This is in accordance with the research of Ann et al. (2012) which states that the more beetroot extract used, the darker the marshmallow color and the brightness value decreases. The redness level (a+) of jelly candy increase with the increase of the beetroot juice ratio. On the other hand, the yellowness level $(b+)$ of jelly candy increase with the increase of the pineapple core juice ratio. 


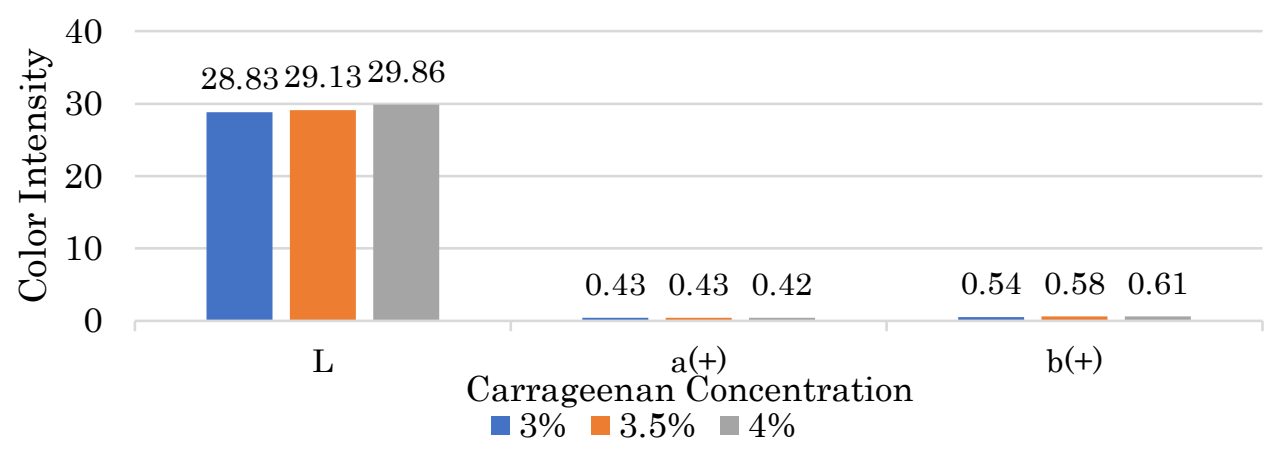

Figure 2. Color Intensity of Jelly Candy by Carrageenan Concentration

Carrageenan concentration had no significant effect on brightness (L), redness $(\mathrm{a}+)$, yellowness $(\mathrm{b}+)$ of jelly candy. Carrageenan is a white powder used as a gelling agent and is used in small concentrations in the product so that its role in the color intensity of the product is not significant.

\section{Organoleptic (Color, Aroma, Taste, Texture)}

Based on the analysis of variance, it is known that there is an interaction $(\mathrm{P}<0,05)$ between the two factors on the organoleptic scores of jelly candy.

Table 9. Organoleptic Scores of Jelly Candy

\begin{tabular}{|c|c|c|c|c|}
\hline Treatments & Color & Aroma & Taste & Texture \\
\hline S1K1 (100\% Beetroot: 0\% Pinec & $3.60^{\mathrm{ab}}$ & $3.16^{\mathrm{a}}$ & $2.84^{\mathrm{a}}$ & $3.16^{\mathrm{a}}$ \\
\hline S1K2 (100\% Beetroot: 0\% Pineapple Core $+3,5 \%$ Carrageenan) & $3.60^{\mathrm{ab}}$ & $3.32^{\mathrm{ab}}$ & $2.96^{\mathrm{a}}$ & $3.28^{\mathrm{ab}}$ \\
\hline S1K3 (100\% Beetroot: 0\% Pine & $3.52^{\mathrm{a}}$ & $3.16^{\mathrm{a}}$ & $3.04^{\mathrm{a}}$ & $3.72^{\mathrm{bc}}$ \\
\hline S2K1 (75\% Beetroot : 25\% Pine & $3.92^{\mathrm{bcd}}$ & $3.72^{\mathrm{bc}}$ & $3.0^{\mathrm{b}}$ & $3.56^{\mathrm{abc}}$ \\
\hline S2K2 (75\% Beetroot : $25 \%$ Pineapple Core $+3,5 \%$ Carrageenan) & $3.84^{\text {abcd }}$ & $3.72^{\mathrm{bc}}$ & $3.76^{\mathrm{b}}$ & $3.32^{\mathrm{ab}}$ \\
\hline S2K3 (75\% Beetroot : $25 \%$ Pineapple Core $+4 \%$ Carrageenan) & $3.80^{\mathrm{abc}}$ & $3.68^{\mathrm{bc}}$ & $3.72^{\mathrm{b}}$ & $3.72^{\mathrm{bc}}$ \\
\hline S3K1 (50\% Beetroot : 50\% Pineapple Core $+3 \%$ Carrageenan) & $4.20^{\mathrm{d}}$ & $3.88^{\mathrm{c}}$ & $4.00^{\mathrm{b}}$ & $3.32^{\mathrm{ab}}$ \\
\hline S3K2 (50\% Beetroot : $50 \%$ Pineapple Core $+3,5 \%$ Carrageenan $)$ & $4.16^{\mathrm{cd}}$ & $3.96^{\mathrm{c}}$ & $4.08^{\mathrm{b}}$ & $3.64 \mathrm{abc}$ \\
\hline S3K3 (50\% Beetroot : 50\% Pineapple Core $+4 \%$ Carrageenan) & $4.20^{\mathrm{d}}$ & $4.00^{\mathrm{c}}$ & $4.08^{\mathrm{b}}$ & $4.00^{\mathrm{c}}$ \\
\hline
\end{tabular}

Mean followed by different letters in the same column differs significantly $(\mathrm{P} \leq 0.05)$

Score Description:

Color:

$1=$ Very Unattractive

$2=$ Unattractive

$3=$ Slightly Attractive

$4=$ Attractive

Aroma:
$1=$ Very Unpleasant
$2=$ Unpleasant
$3=$ Slightly Unpleasant
$4=$ Pleasant
$5=$ Very Pleasant
Taste:
$1=$ Very Bad
$2=\mathrm{Bad}$
$3=$ Quite Bad
$4=$ Good
$5=$ Very Good
Texture:
$1=$ Very Unchewed
$2=$ Unchewed
$3=$ Slightly chewy
$4=$ Chewy
$5=$ Very Chewy

The higher ratio of pineapple core juice is preferred by the panelists because it produces jelly candy with brighter and more attractive colors. It can be caused by the xanthophyll pigment contained by pineapple that reduces the dark color of beetroot. The pineapple core juice can reduce the unpleasant aroma and flavor of beetroot because it still has a distinctive pineapple aroma, which comes from volatile components, namely methyl ester and, ethyl ester groups (Zulkifli et al., 2018). The higher concentration of carrageenan is preferred by the panelists in 
terms of texture, because it creates a better texture of jelly candy. Carrageenan can bind water very well and increases the chewiness of jelly candy. The gel matrix formed will absorb the water inside and create a strong and supple structure (Giyarto et al., 2019).

\section{Determination of Best Treatment}

Table 10. Determination of Best Treatment (De Garmo Method)

\begin{tabular}{lcc}
\hline \multicolumn{1}{c}{ Treatments } & Total & Rank \\
\hline S1K1 (100\% Beetroot: 0\% Pineapple Core + 3\% Carrageenan) & 0.172 & 9 \\
S1K2 (100\% Beetroot: 0\% Pineapple Core + 3,5\% Carrageenan) & 0.418 & 7 \\
S1K3 (100\% Beetroot: 0\% Pineapple Core + 4\% Carrageenan) & 0.329 & 8 \\
S2K1 (75\% Beetroot : 25\% Pineapple Core + 3\% Carrageenan) & 0.466 & 6 \\
S2K2 (75\% Beetroot : 25\% Pineapple Core + 3,5\% Carrageenan) & 0.573 & 4 \\
S2K3 (75\% Beetroot : 25\% Pineapple Core + 4\% Carrageenan) & 0.470 & 5 \\
S3K1 (50\% Beetroot : 50\% Pineapple Core + 3\% Carrageenan) & 0.725 & 2 \\
S3K2 (50\% Beetroot : 50\% Pineapple Core + 3,5\% Carrageenan) & 0.664 & 3 \\
S3K3 (50\% Beetroot : 50\% Pineapple Core + 4\% Carrageenan) & 0.810 & 1 \\
\hline
\end{tabular}

Based on Table 10, the best treatment was obtained in the S3K3 treatment, with a 50\%: $50 \%$ ratio of beetroot juice and pineapple core juice and the addition of $4 \%$ carrageenan with a moisture content of $14.79 \%$, ash content $0.72 \%$, reducing sugar $1.81 \%$, antioxidant activity $71.23 \%$, texture $59.6 \mathrm{~N}$, brightness level (L) 34.53 , redness level (a+) 0.3, yellowness level $(\mathrm{b}+)$ 0.83, then the color score 4.2 (attractive), aroma score 4 (pleasant), taste score 4.16 (good), texture score 3.96 (slightly chewy).

\section{Comparison of Best Treatment with Control Sample and Indonesian National Standard (SNI)}

The 3\% concentration of commercial carrageenan was chosen as a control sample based on the best treatment of a previous study done by Giyarto et al. (2019) in the making of pineapple core jelly candy.

Table 11. Comparison of Best Treatment to Control Sample

\begin{tabular}{lrrrrc}
\hline \multicolumn{1}{c}{ Parameters } & S3K3 & Control & T. Value & T. Table & Notation \\
\hline Moisture Content (\%) & 14.79 & 13.89 & 1.742 & 2.7760 & Ns \\
Ash Content (\%) & 0.72 & 0.57 & 3.831 & 2.7760 & $* *$ \\
Reducing Sugar (\%) & 1.81 & 1.16 & 1.801 & 2.7760 & Ns \\
Antioxidant Activity (\%) & 71.23 & 77.67 & 1.284 & 2.7760 & $\mathrm{Ns}$ \\
Texture (N) & 59.60 & 55.00 & 0.611 & 2.7760 & $\mathrm{Ns}$ \\
Brightness (L) & 34.53 & 29.97 & 4.600 & 2.7760 & $* *$ \\
Redness (a+) & 0.30 & 0.33 & 1.000 & 2.7760 & $\mathrm{Ns}$ \\
Yellowness (b+) & 0.83 & 0.73 & 1,340 & 2.7760 & $\mathrm{Ns}$ \\
Organoleptic (Color) & 4.20 & 4.28 & 0,360 & 2.0106 & $\mathrm{Ns}$ \\
Organoleptic (Aroma) & 4.00 & 4.08 & 0,340 & 2.0106 & $\mathrm{Ns}$ \\
Organoleptik (Taste) & 4.16 & 4.52 & 2,410 & 2.0106 & $* *$ \\
Organoleptik (Texture) & 3.96 & 4.44 & 2,290 & 2.0106 & $* *$ \\
\hline Note: & & & & &
\end{tabular}

Note: $\mathrm{ns}=$ not significant

$* *=$ very significant 
This test used the T-Test method presented in Table 11. Several parameters that showed no significant difference between the best treatment and the control were moisture content, reducing sugar, antioxidants, texture, redness color (a+), yellowish color $(b+)$, organoleptic color, and organoleptic taste. Based on these results, S3K3 treatment with the use of $4 \%$ extracted carrageenan has the ability to approach $3 \%$ commercial carrageenan.

Table 12. Comparison of Best Treatment to SNI

\begin{tabular}{llr}
\hline Parameters & SNI & S3K3 \\
\hline Moisture Content (\%) & Max. 20 & 14,79 \\
Ash Content (\%) & Max. 3 & 0,72 \\
Reducing Sugar (\%) & Max. 25 & 1,81 \\
\hline
\end{tabular}

The best treatment of S3K3 was also compared with SNI 3547.02:2008 (soft confectionery) as shown in Table 12. The parameters compared were moisture content, ash content, and reducing sugar. The results show that the S3K3 treatment has met the three criteria of SNI 3547.02:2008. The best treatment S3K3 has a value of $14.79 \%$ moisture content, $0.72 \%$ ash content and $1.81 \%$ reducing sugar.

\section{CONCLUSION}

There are interactions between the different ratios of beetroot juice with pineapple core juice and carrageenan concentration on moisture content, ash content, texture, color score, aroma score, taste score, texture score of jelly candy. The best treatment was obtained in the S3K3 treatment, consisting of 50\%: 50\% ratio of beetroot juice and pineapple core juice and the addition of $4 \%$ carrageenan. S3K3 treatment has a moisture content $14.79 \%$, ash content $0.72 \%$, reducing sugar $1.81 \%$, antioxidant activity $71.23 \%$, texture $59.6 \mathrm{~N}$, brightness level (L) 34.53 , redness level $(\mathrm{a}+)$ 0.3, yellowness level $(\mathrm{b}+)$ of 0.83 , then the color score 4.2 (attractive), aroma score 4 (pleasant), taste score 4.16 (good), texture score 3.96 (slightly chewy).

\section{REFERENCES}

Andriani, Z., A. G. Fasya., A. Hanapi. 2015. Antibacterial Activity of The Red Algae Eucheuma cottonii Extract from Tanjung Coast, Sumenep Madura. Jurnal Alchemy, 4 (2), pp 93-100. DOI: https://doi.org/10.18860/al.v4i2.3197.

Ann, K. C., T. I. P. Suseno., A. R. Utomo. 2012. Pengaruh Perbedaan Konsentrasi Ekstrak Bit Merah dan Gelatin terhadap Sifat Fisikokimia dan Organoleptik Marshmallow Beet. Jurnal Teknologi Pangan dan Gizi, 11 (2), pp 28-36. DOI: https://dx.doi.org/10.33508/jtpg.v11i2.1472.

AOAC. 2005. Official methods of analysis of the Association of Analytical Chemist. Association of Official Analytical Chemist Inc. Virginia USA.

Badan Standardisasi Nasional. 2008. SNI 3547.2-2008: Kembang Lunak (Jelly). Badan Standardisasi Nasional. Jakarta. 
Badan Standardisasi Nasional. 2017. SNI 8391.1-2017: Karagenan Murni (Refined carrageenan) Bagian 1: Kappa Karagenan. Badan Standardisasi Nasional. Jakarta.

Bunga, S. M., R. I. Montolalu., J. W. Harikedua., L. A. Montolalu., A. H. Watung., N. Taher. 2013. Karakteristik Sifat Fisika Kimia Karaginan Rumput Laut Kappaphycus alvarezii pada Berbagai Umur Panen yang Diambil dari Daerah Perairan Desa Arakan Kabupaten Minahasa Selatan. Jurnal Media Teknologi Hasil Perikanan, 1 (2), pp 54-58. DOI: https://doi.org/10.35800/mthp.1.2.2013.767.

Cahyanti, S. 2019. Kajian Ekstraksi Karagenan dengan Berbagai Umur Kemasakan Air Kelapa (Cocos viridis) terhadap Karakteristik Fisikokimia serta Aplikasinya pada Permen Jelly Apel. Skripsi. Univeristas Muhammadiyah Malang. Malang.

Campo, V. L., D. F. Kawano., D. B. S. Junior., I. Carvalho. 2009. Carrageenans: Biological Properties, Chemical Modifications and Structural Analysis. Journal of Carbohydrate, 77 (2), pp 167-180. DOI: https://doi.org/10.1016/j.carbpol.2009.01.020.

Datuyanan, I. S., B. H. Simanjuntak., A. W. Setiawan., Y. A. Handoko. 2020. Studi Penambahan Serai (Cymbopogon citratus) dan Temu Mangga (Curcuma mangga) terhadap Karakteristik Fisikokimia dan Organoleptik Minuman Sari Umbi Bit (Beta vulagris L.). Jurnal Agroteknolof, 14 (1), pp 23-32. DOI: https://doi.org/10.19184/j-agt.v14i01.15396.

Diharmi, A., D. Fardiaz., N. Andarwulan., E. S. Heruwati. 2011. Karakteristik Karagenan Hasil Isolasi Eucheuma spinosum (Alga Merah) dari Perairan Sumenep Madura. Jurnal Perikanan dan Kelautan, 16 (1), pp 117-124. DOI: http://dx.doi.org/10.31258/jpk.16.02.\%25p.

Distantina, S., R. Fadilah., Wiratni., M. Fahrurrozi. 2010. Mekanisme Proses Tahap Ekstraksi Karagenan Dari Eucheuma cottonii menggunakan Pelarut Alkali. Jurnal Agritech, 32 (4), pp 397-402. DOI: https://doi.org/10.22146/agritech.9583.

Engka, D. L. 2016. Pengaruh Konsentrasi Sukrosa dan Sirup Glukosa terhadap Sifat Kimia dan Sensoris Permen Keras Belimbing Wuluh (Averrhoa bilimbi L.). Jurnal Cocos, 7 (3), pp 1-10. https://doi.org/10.35791/cocos.v7i3.12533.

Fajarini, L. D. R., I. G. A. Ekawati., P. T. Ina. 2018. Pengaruh Penambahan Karagenan terhadap Karakteristik Permen Jelly Kulit Anggur Hitam (Vitis vinifera). Jurnal Itepa, 7 (2), pp 43-52. DOI: https://doi.org/10.24843/itepa.2018.v07.i02.p05.

FAO Food and Agriculture Organization. 2014. Specifications: Carrageenan. FAO. Roma.

Giyarto. G., S. Suwasono, P. O. Surya. 2019. Karakteristik Permen Jelly Jantung Buah Nanas dengan Variasi Konsentrasi Karagenan dan Suhu Pemanasan. Jurnal Agroteknologi, 13 (2), pp 118-130. DOI: https://doi.org/10.19184/jagt.v13i02.10456. 
Hanifan, F., A. Ruhana., D. Y. N. Hidayati. 2016. Pengaruh Substitusi Sari Umbi Bit (Beta vulgaris L.) terhadap Kadar Kalium, Pigmen Betalain dan Mutu Organoleptik Permen Jeli. Jurnal Majalah Kesehatan FK UB, 3 (1), pp 33-41. DOI: https://doi.org/10.21776/ub.majalahkesehatan.003.01.5.

Hayat, I. U., E. Suryanto., J. Abidjulu. 2015. Pengaruh Sari Buah Nanas (Ananas comosus L.) terhadap Aktivitas Antioksidan pada Ekstrak Tongkol Jagung (Zea mays L.). Jurnal Ilmiah Fantasi, 3 (4), pp 51-57. DOI: https://doi.org/10.35799/pha.4.2015.8837.

Hossain, M. F., S. Akhtar., M. Anwar. 2015. Nutritional Value and Medicinal Benefits of Pineapple. International Journal of Nutrition and Food Sciences, 4(1), pp 84-88. DOI: https://doi.org/10.11648/j.ijnfs.20150401.22.

Imaduddin, A. H., dan W. H. Susanto. 2017. Pengaruh Tingkat Kematangan Buah Belimbing (Averrhoa carambola L.) dan Proporsi Penambahan Gula terhadap Karakteristik Fisikokimia dan Organoleptik Lempok Belimbing. Jurnal Pangan dan Agroindustri, 5 (2), pp 45-57.

Kale, R. G., A. R. Sawate., R. B. Kshirsagar., B. M. Patil., R. P. Mane. 2018. Studies on Evaluation of Physical and Chemical Composition of Beetroot (Beta vulgaris L.). International Journal of Chemical Studies, 6(2), pp 29772979. DOI: https://dx.doi.org/10.22271/chemi.

Lembong, E., dan Utama, G.L. 2021. Potensi Pewarna dari Bit Merah (Beta vulgaris L.) sebagai Antioksidan. Jurnal Agercolere, 3(1), pp 7-13. DOI: 10.37195/jac.v3i1.122.

Malik, I. 2010. Pembuatan Permen Jelly. Universitas Sumatera Utara. Medan.

Meilianti, M. 2020. Karakterisasi Permen Jelly Umbi Bit Merah (Beta vulgaris L.) dengan Penambahan Ekstrak Buah Sirsak dan Variasi Pektin. Jurnal Distilasi, 3(2), pp 39-47. DOI: https://doi.org/10.32502/jd.v3i2.2934.

Novatama, S.M., K. Ersanghono., Supartono. 2016. Identifikasi Betasianin dan Uji Antioksidan Ekstrak Buah Bit Merah (Beta vulgaris L.). Indonesian Journal of Chemical Science, 5(3), pp 1-7. DOI: https://doi.org/10.15294/ijcs.v4i1.4765.

Nuraini, V., M. Karyantina. 2019. Pengaruh Waktu Pemanasan dan Penambahan Air terhadap Aktivitas Antioksidan Selai Buah Bit (Beta vulgaris L.). Jurnal Teknologi Pangan, 2(1), pp 26-36. DOI: http://dx.doi.org/10.26418/jft.v2i1.38021.

Paramita, D. I., F. S. Pranata., Y. R. Swasti. 2021. Kualitas Selai Lembaran Kombinasi Umbi Bit Merah (Beta vulgaris L. var. rubra L.) dan Ekstrak Pektin Dami Nangka (Artocarpus heterophyllus Lamk.). Jurnal Teknologi Pangan dan Gizi, 20 (1), pp 52-62.

Rahayuningtyas, A., dan S. I. Kuala. 2016. Pengaruh Suhu dan Kelembaban Udara pada Proses Pengeringan Singkong (Studi Kasus: Pengering Tipe Rak). Ethos (Jurnal Penelitian dan Pengabdian Masyarakat), 4 (1), pp 99104. DOI: https://doi.org/10.29313/ethos.v0i0.1663.

Samantha, K., T. I. P. Suseno., A. R. Utomo. 2019. Pengaruh Konsentrasi Karaginan terhadap Karakteristik Fisikokimia dan Organoleptik Selai 
Murbei (Morus nigra L.) Lembaran. Jurnal Teknologi Pangan dan Gizi, 18 (2), pp 119-125. DOI: https://doi.org/10.33508/jtpg.v18i1.1988.

Saputri, R.K., A. A. Bari., R. I.K. Pitaloka. 2021. Daya Terima Konsumen terhadap Jelly Drink Belimbing Wuluh. Jurnal Teknologi Pangan, 12 (1), pp 131139. DOI: https://doi.org/10.35891/tp.v12i1.2244.

Shaliha, L. A., S. B. M. Abduh., A. Hintono. 2017. Aktivitas Antioksidan, Tekstur dan Kecerahan Ubi Jalar Ungu (Ipomoea batatas) yang Dikukus pada Berbagai Lama Waktu Pemanasan. Jurnal Aplikasi Teknologi Pangan, 6 (4), pp 141-144. DOI: http://dx.doi.org/10.17728/jatp.260.

Slavov, A., V. Karagyozov., P. Denev., M. Kratchanova, M., K. Chr. 2013. Antioxidant Activity of Red Beet Juices Obtained After Microwave and Thermal Pretreatments. Czech Journal of Food Science, 2 (31), pp 139147. DOI: https://doi.org/10.17221/61/2012-CJFS.

Souripet, A. 2015. Komposisi, Sifat Fisik dan Tingkat Kesukaan Nasi Ungu. Jurnal Agrotekno, 4 (1), pp 25-32.

Stojanovic, S., Z. J. Filipovic., B. Mugosa. 2013. Consumer Acceptance of Functional Foods in Montenegro. Montenegrin Journal of Economics, 9 (3), pp 65-74.

Sudarmadji, S., B. Haryono., S. Suhardi. 2007. Analisa Bahan Makanan dan Pertanian. Kanisius. Yogyakarta.

Utomo, S. 2016. Pengaruh Konsentrasi Pelarut (n-Heksana) terhadap Rendemen Hasil Ekstraksi Minyak Biji Alpukat untuk Pembuatan Krim Pelembab Kulit. Jurnal Konversi, 5(1), pp 39-47. DOI: https://doi.org/10.24853/konversi.5.1.39-47.

Yue, X., Z. Xu. 2008. Changes of Anthocyanins, Anthocyanidins, Antioxidant Activity in Bilberry Extract during Dry Heating. Journal Food Science, 73 (6), pp C494-C499. DOI: https://doi.org/10.1111/j.17503841.2008.00845.x.

Zainuddin, M. F., R. Shamsudin., M. Mokhtar, D. Ismail. 2014. Physicochemical Properites Pineapple Plant Waste Fiers from The Leaves and Stem Different Varieties. Journal Bio Resources, 9 (3), pp 5311-5324.

Zulkifli., Y. Yusmarini., R. Efendi. 2018. Pemanfaatan Wortel dan Bonggol Nanas dalam Pembuatan Permen Jelly. Jurnal Online Mahasiswa Universitas Riau, 5 (6), pp 404-417. 